Article

\title{
Does Integrated Reporting Enhance the Value Relevance of Information? Evidence from Sri Lanka
}

\author{
Thilini Cooray ${ }^{\oplus}$, Samanthi Senaratne ${ }^{\circledR}$, A. D. Nuwan Gunarathne * ${ }^{*}$, Roshan Herath and \\ Dileepa Samudrage
}

Department of Accounting, University of Sri Jayewardenepura, Nugegoda 10250, Sri Lanka; thilinicooray@sjp.ac.lk (T.C.); samanthisenaratne@sjp.ac.lk (S.S.); roshanherath@sjp.ac.lk (R.H.); dileepask@sjp.ac.lk (D.S.)

* Correspondence: nuwan@sjp.ac.lk; Tel.: +94-7736-1188

Received: 28 July 2020; Accepted: 28 September 2020; Published: 4 October 2020

\begin{abstract}
This paper examines the relationship between the level of integrated reporting (IR) based on the extent of adoption of the International Integrated Reporting Framework (IIRF) and the firm value (a proxy for value relevance of IR) in Sri Lanka, where the adoption of IR is a voluntary exercise. Using a comprehensive disclosure checklist, 117 integrated reports were content-analyzed, and then two regression models assessed the value relevance of IR disclosure. The study notes an increasing trend toward the adoption of IIRF in the preparation of integrated reports overall, as well as of each content element of IIRF. However, this rising trend has not significantly impacted the firm value by itself. Hence, this study's findings do not support the enlightened stakeholder's view on the subject of IR in Sri Lanka. Instead, it shows a significant positive relationship with the firm value when combined with the information on earnings (earnings per share), indicating that IIRF-compliant IR improves the value relevance of accounting information. This study offers insights for policymakers, professional accounting bodies, and practitioners on how investors make use of the information disclosed in integrated reports in their decision-making.
\end{abstract}

Keywords: enlightened stakeholder theory; firm value; integrated reporting; Sri Lanka; value relevance

\section{Introduction}

As a new reporting model, integrated reporting (IR) has gained momentum with the issuance of the International Integrated Reporting Framework (IIRF) in 2013 by the International Integrated Reporting Council (IIRC). These guidelines seem to have a profound impact on the adopters of IR, as iterated by many prior studies that have reported a growing tendency to adopt IIRF in the preparation of integrated reports [1-3]. In this context, it is essential to assess its impact on IR users.

As IR aims to explain to the providers of financial capital how an entity creates value over time, one of the main questions that arises is whether investors find integrated reports more decision-useful than traditional annual reports [4-6]. Although several studies have seemingly addressed this issue, they have only provided inconclusive and mixed results while being constrained by their choice of method and contextual setting. For instance, in South Africa, while Lee and Yeo [7] found a positive association between the quality of IR information and the firm value, Baboukardos and Rimmel [8] found a sharp increase in the earnings valuation with a corresponding decline in the value relevance of net assets. Further, Zhou et al. [9] suggest that IR provides incrementally useful information to the capital market over and above the existing reporting mechanisms. While all these studies took place in a mandatory setting, they did not consider the extent of adoption of IR in analyzing the value relevance of IR, except for Lee and Yeo [7]. Moving beyond a mandatory setting, Cortesi and Vena [10], in a cross-country study, found IR enhances corporate disclosure, reduces information 
asymmetries, and increases the quality of reported earnings per share, but does not positively influence the value relevance of book value. Although Cortesi and Vena [10] extended the value relevance of IR to voluntary contexts, a severe lapse in their study was found due to their neglect of the extent of adoption of IIRF in the preparation of integrated reports More specifically, Cortesi and Vena [10] have identified the adoption of IR only as a dummy variable in the model, where 1 is given if a company has adopted IR and otherwise 0 is assigned.

The extent of adoption of IIRF is particularly crucial in view of the discretionary nature of IR disclosures, which allows considerable flexibility for companies when deciding on how to narrate their story of value creation. Further, the principle-based nature of IIRF does not prescribe specific key performance indicators (KPIs), measurement methods, or disclosures on specific items, thus giving much leeway to companies in preparing their integrated reports. This would inevitably result in wide disparities in the extent of IR among the reporting entities, which, in turn, would significantly affect value relevance. The adoption of IIRF is becoming merely a ceremonial or normative practice despite its wide popularity $[2,11,12]$ while inattention to the extent of reporting can seriously undermine the results of the above studies.

In this context, this study examines the relationship between the intensity of IR based on the extent of adoption of IIRF and the value relevance of the information disclosed in the integrated reports in a developing country context where IR is a voluntary exercise. Hence, this study differs from previous studies, such as those by Baboukardos and Rimmel [8], Zhou et al. [9], and Cortesi and Vena [10], that evaluated the value relevance of IR without considering the extent of adoption of IIRF. Further, this study differs from that by Lee and Yeo [7], who analyzed the extent of adoption of IIRF in a mandatory context, and by Cortesi and Vena [10], who did not consider the value relevance of IR in the context of a particular country.

This study contributes to the value relevance literature by analyzing the value relevance of IR using both price and return models [13] against the competing views of the relationship between IR and firm value. IR can increase the firm value, as it will allow shareholders to better articulate the linkage between strategy, business model, and value creation; however, it can have a negative impact on the firm value owing to the disclosure of the proprietary nature of information as in the strategy and business model. Hence, alternative proxy variables for the value relevance of information [14] are considered in the study based on the enlightened stakeholder theory [15], which accepts maximization of the long-run value of the firm as the criterion for making the requisite tradeoffs among its stakeholders.

The developing country selected for the study is Sri Lanka, a country that has witnessed a high rate of diffusion of IR in recent years $[11,16]$ despite it being a voluntary exercise. However, Gunarathne and Senaratne [11] also found that though IR has been an efficient choice for early adopters in Sri Lanka, for many late adopters, it was becoming a fashionable choice. Many late adopters have, therefore, neither realized the benefits of IR adoption nor paid attention to the guiding IIRF principles. Hence, with the increasing number of companies adopting IR in Sri Lanka, it has become necessary to assess the extent to which they have complied with IIRF in the preparation of integrated reports and whether the investors value the information provided in the integrated reports in compliance with IIRF. Our study addresses this issue by examining the listed companies that have prepared integrated reports for three consecutive years from 2015/2016 to 2017/2018. However, this study was carried out with a small sample, which is inevitable owing to the limited size of the stock market of the country.

This study contributes to the existing literature in several ways. First, it comprehensively assesses how companies comply with IIRF in producing integrated reports using a detailed checklist prepared based on the content elements (The content elements are considered as they identify the disclosures that the companies are expected to provide in an integrated report) of IIRF. This checklist differs from the indices of Stent and Dawler [17], Kilic and Kuzey [18], and Adhikariparajul et al. [3] in its extensive coverage of the areas covered under the content elements of IIRF. Second, the study contributes to the ongoing debate on whether IR impacts the value relevance of the information disclosed by companies by examining its association with the intensity and trends of IR based on IIRF. This is important, as the 
previous studies have mostly omitted a thorough examination of integrated reports based on IIRF in their analysis. Third, the study examines the impact of IR on firm value based on both price and return models from the broad perspective of firm value while focusing on the inherent specification issues associated with these models. This is important, as most of the other studies have focused on value relevance based on a single model [13], which inhibits consideration of the value relevance of IR from a broad perspective [19]. Fourth, this study provides insights into IR from the perspective of a developing country in South Asia, where studies on new reporting models are limited. Despite the economic, geographic, and social significance of this region, its lack of understanding of the role of business in creating a sustainable future for itself and the region can significantly undermine the much-needed inclusive and balanced development [11]. This study highlights the role of new corporate reporting models in promoting investor confidence, which can act as a catalyst for economic development while creating value for a wider set of stakeholders.

The rest of the paper is organized as follows: Section 2 provides the literature review; Section 3 presents the theoretical framework and hypotheses development; Section 4 describes the methodology; Section 5 presents the findings, and Section 6 presents the discussion followed by conclusion.

\section{Literature Review}

This section reviews the literature on the concept of IR and value relevance of disclosures with specific reference to the information disseminated through integrated reports.

\subsection{IR}

IR entails a new and innovative approach to the current corporate reporting practice $[20,21]$ as it combines most of the material elements of information currently reported in separate reporting strands into a coherent whole and explains how they affect the ability of an organization to create and sustain value in the short, medium, and long term [22,23]. The International Integrated Reporting Council (IIRC) [24] (p. 7) denotes that IR is a process founded on integrated thinking and a result of the preparation of an integrated report, which is a "concise communication about how an organization's strategy, governance, performance, and prospects, in the context of/its external environment, lead to the creation of value over the short, medium, and long term". Thus, IR aims at a holistic corporate reporting model $[25,26]$ that depicts the inter-connectivity between the strategies of a firm, its performance, and the economic, social, and environmental context within which it operates. Hence, several benefits are expected to stem from IR, which fall into three broad categories: Internal benefits, external market benefits, and management of regulatory risk [27].

IIRF adopts a principle-based approach "to strike an appropriate balance between flexibility and prescription that recognizes the wide variation in the particular circumstances of different organizations while allowing for a sufficient degree of comparability across organizations to meet relevant information needs" [24] (p. 4). It mainly focuses on the disclosure of factors that would substantially affect an organization's ability to create value in the short, medium, and long term. Hence, the purpose of IIRF is to formulate the guiding principles and content elements that decide the overall content of an integrated report and to explain the fundamental concepts that underpin them [24] (see Table 1). 
Table 1. International Integrated Reporting Framework (IIRF) guidelines based on International Integrated Reporting Council (IIRC) [24].

\begin{tabular}{lll}
\hline Guiding Principles & Content Elements & Fundamental Concepts \\
\hline & $\begin{array}{l}\text { Organizational overview and external } \\
\text { environment }\end{array}$ & \\
Strategic focus and future orientation & Governance & Value creation for the organization \\
Connectivity of information & Business model & and for others \\
Stakeholder relationships & Risks and opportunities & The capitals \\
Materiality & Strategy and resource allocation & \\
Conciseness & Performance & \\
Reliability and completeness & Outlook & \\
Consistency and comparability & Basis of preparation and presentation & \\
&
\end{tabular}

The 'guiding principles' underpin the preparation and presentation of an integrated report with information on the content of the report and how the information should be presented. The 'content elements,' which are fundamentally linked with each other, present the information required in an integrated report. Such information should be presented so as to bring out the connection between these eight-content elements. On the other hand, the 'fundamental concepts' underpin and reinforce the requirements and guidance in the IIRF.

Since IR is a new reporting practice, the studies on the subject are limited but growing, and some researchers have emphasized the need for more empirical research on the application and impact of IR [5,28-30]. In this respect, several researchers have assessed the level of adoption of IR in different countries or industries $[1-3,12,17,18]$, which is frequently measured using different indices or checklists based on IIRF. However, the findings indicate mixed results. Deloitte [1] reports the number of companies complying with the content elements of IIRF has increased over time and that their IR is maturing. Ahmed Haji and Anifowose [2] and Herath et al. [12] reported an increasing trend of IR practice in South Africa and in Sri Lanka. However, both the studies raised concerns regarding the content and quality of these reports. In contrast, Adhikariparajul et al. [3] signified a higher level of adoption in accordance with IIRF in British higher educational institutes. These findings point to the need for further examination of the level of adoption of IR and how it can impact the importance of disclosures to the stakeholders

\subsection{Value Relevance of Information in $I R$}

The value relevance of disclosures has been a popular area of study among accounting researchers over a long period of time. In these studies, value relevance is defined as the ability of information disclosed by financial statements to capture and summarize firm value [31] and the focus is made on the association between the empirical relation between stock market values (or changes in values) and various accounting numbers to assess the usefulness of accounting numbers in equity valuation [13]. Thus, the Ohlson model [32] was adopted in most studies to explore the relationship between the market value of equity and the two main financial reporting variables, namely, the book value of equity per share and earnings per share, which represent the balance sheet and the income statement, respectively.

Lately, value relevance studies in accounting have stressed the relationship between corporate social responsibility (CSR) disclosures and the firm value [33-36]. However, they have observed the association between CSR disclosures and the firm value in different country contexts, which provide contradictory evidence (The studies of de Klerk and de Villers [34], and Uyar and Kiliç [35] report a positive relationship between CSR disclosures and firm value in South Africa and Turkey, respectively. In contrary, Moneva and Cuellar [33] show contradictory evidence on the association between financial and non-financial environmental disclosures with firm value in Spanish companies). This seems to indicate that the voluntary nature of reporting, such as CSR disclosures, can have a bearing on this association.

Since companies display considerable flexibility and discretion in providing voluntary disclosures [37,38], they decide the appropriate level of disclosure by comparing the benefits (e.g., lower 
cost of capital resulting from a reduction in information asymmetry) [37] and costs (e.g., revealing sensitive proprietary information to competitors) $[39,40]$ associated with the provision of information. Hence, IR being mainly a voluntary disclosure initiative, the companies would display a cross-sectional variation in the provision of relevant disclosures. In this context, the value relevance of IR is a critical consideration in most countries except South Africa, where it is a mandatory requirement.

The studies that have examined the effects of IR have a positive impact of IR from a capital market perspective. In this respect, Lee and Yeo [7] reported a positive association between the quality of IR in terms of the adoption of IIRF and the firm value measured by Tobin's Q. Further, Baboukardos and Rimmel [8] reported that with the issuance of an integrated report, the value relevance of earnings increased. Zhou et al. [9] showed IR provides incrementally useful information to the capital market over and above the existing reporting mechanisms. Cosma et al. [41] also found that the stock prices of companies positively react to IR award announcements. All these studies have been conducted in South Africa, where the adoption of IR is mandatory.

Similar findings are also reported in studies on the effects of IR adoption in a voluntary context. Loprevite et al. [42] found that the value relevance of accounting information is higher in IR-adopting companies than in non-adopters in the European Union. In their study covering 57 countries, where IR is adopted voluntarily, Cortesi and Vena [10] showed IR enhances corporate disclosure, reduces information asymmetries, and increases the quality of reported earnings per share. On the other hand, Vitolla et al. [43] showed a positive association between IR quality and cost of capital based on a sample of 116 international firms engaged in IR. Flores et al. [44] reported that, based on a study carried out in North America and Continental Europe, IR increases the analyst's ability to forecast earnings. This study also highlights that IR improves the analysts' ability to predict earnings to a larger extent in North America than in Continental Europe owing to the shareholder-based corporate governance approach in the former compared to the stakeholder-based governance approach in the latter.

Further, Landau et al. [45], using a sample of 50 blue-chip companies in Europe, found that IR plays a role in the market valuation of a firm's equity, where these findings indicate a negative impact on market valuation unless firms publish an integrated report with the assurance of a big four audit firm and prepare their report according to the newest GRI guidelines. This finding is consistent with IIRC's aim to provide information on how an entity can create and sustain value for the use of capital providers, who are considered the primary audience of IR. Thus, the extant literature shows that the preparation of integrated reports, which combine all the material information of an entity, has contributed to improving the value relevance of corporate disclosures.

These studies that examined the value relevance of IR used various proxy variables (see Table 2). Of these methods, the price model and the return model are the most common approaches used in value relevance studies in general [13]. However, these two methods could produce contradictory results owing to the serious specification problems associated with each model despite both being based on the same theoretical foundation [32] and on the linear information model. Specifically, the price model is affected by 'scale effect' and the return model is affected by 'accounting recognition lag' and 'transitionary earning' [13]. Since there is no perfect solution to these problems, the best option is to use both the models [13].

Table 2. Measures for value relevance of integrated reporting (IR) in prior studies.

\begin{tabular}{ll}
\hline Authors & Measure for Value Relevance of IR \\
\hline Lee and Yeo [7] & Firm value measured by Tobin Q \\
Baboukardos and Rimmel [8] & Price-model (market price of equity of a firm) \\
Zhou et al. [9] & Analyst earnings forecast \\
Cortesi and Vena [10] & Price-model (market price of equity of a firm) \\
Cosma et al. [41] & Abnormal share returns (Event study methodology) \\
Loprevite et al. [42] & Price-model (market price of equity of a firm) \\
Vitolla et al. [43] & Cost of equity capital \\
Flores et al. [44] & Analyst forecasts (Accuracy and coverage of analysts) \\
\hline
\end{tabular}


Though the value relevance of IR has been considered along different dimensions, there are still several unanswered questions in this respect. They are as follows: How does the level of adoption of IIRF impact the value relevance in a particular country context where IR is a voluntary exercise? What proxy variables for value relevance of IR should be used to better capture and summarize firm value? Finally, would the results be different based on the proxy variables selected? Hence, this study examines how the level of adoption of IIRF in IR can impact the firm value, which is measured based on both price and return models to give a broad perspective to firm value [19] considering the presence of various proxy variables in this respect [14].

The study explores this question based on the theoretical perspective of the enlightened value maximization theory (enlightened stakeholder theory) proposed by Jensen [15], as explained in Section 3.

\section{Theoretical Framework and Hypotheses Development}

Jensen's [15] enlightened stakeholder theory offers a coherent theoretical lens to explore the value creation proposition provided in IIRF. It is similar to the instrumental stakeholder theory [46], which views stakeholder management as a means to enhance the financial performance of a firm [47]. However, "the key distinction between the two theories is that Jensen [15] adds value maximization as the overriding goal of a firm and becomes the scorecard by which a company's success is gauged" [47] (p. 930). Hence, the enlightened stakeholder theory posits that stakeholders play a crucial role in a firm's operations and focuses on these stakeholders through various activities contributing to shareholder value [48].

Jensen [15] suggests that focusing on a single objective, e.g., increasing the long-term market value, maximizes shareholder wealth while best advancing social welfare. In other words, "if shareholder wealth is maximized, social welfare is maximized as well" [49]. Hence, maximization of the long-run value of the firm is the criterion for making the requisite tradeoffs among its stakeholders [50,51], and effective management of a firm and stakeholder relationships can enable the long-term enhancement of the company's economic performance [52]. Accordingly, shareholders are not a special constituency that ranks above all others, but long-term share value is an essential determinant of the long-term firm value. Hence, Jensen [15] argues that value creation paves the way for management to assess the trade-offs that must be made among competing constituencies and allows for principled decision-making independent of the personal preferences of managers and directors.

Following a similar argument to that of the enlightened stakeholder theory, IIRC (24) states that value is not created by or within an organization alone. It is influenced by the external environment, created through the relationships with stakeholders, and depends on various resources. The value created is manifested in the increases, decreases, or transformations in capital caused by the business activities and outputs of an organization. Hence, according to IIRF, the value created by an organization includes two components: The value created for the organization itself and others (i.e., stakeholders and society at large). As the providers of capital, shareholders are interested in both. The value created for the organization itself will generate the return for the capital providers and may be affected by the value created for the stakeholders and society at large.

This shows that though it is argued that value creation in the IIRF could imply that IR represents a form of disclosure addressed exclusively to the providers of financial capital [53], the concept of value considered in IR is much broader [54-56]. Thus, the concept of value should be considered from a broader perspective and understood as the value for all stakeholders and society at large $[57,58]$. From this perspective, value creation is not confined to shareholders, but rather considered from a broader perspective based on the quality of the relations with the main categories of stakeholders, including employees, customers, suppliers, and community [55,59]. According to the enlightened stakeholder theory, this value creation should be reflected in the long-term market value of a firm, as it denotes the success of a firm in managing six capitals through the effective management of stakeholders. 
Supporting the enlightened stakeholder theory, Cook et al. [48] found firms with high CSR performance invest efficiently in profitable projects and innovations, which, in turn, lead to higher profitability and firm value. Similarly, by examining the correlation between firm value, stakeholder management, and compensation, Benson and Davidson [47] found the results to be consistent with Jensen's [15] enlightened value maximization theory. Moreover, analyzing the top 100 corporate citizen firms, Queen [60] showed how the firms can integrate financial and social objectives in the central corporate strategies to achieve good social and financial performance that can be converted into shareholder wealth. Thus, the firms that follow integrated thinking underpinning IR devote various forms of capital or resources to socially responsible initiatives as a means of maximizing long-run firm value [61].

Hence, based on the argument advanced in this theory, this study hypothesizes the relationship between the level of adoption of IIRF in IR and the firm value, which is measured in terms of both market price and the market return as follows:

Hypothesis 1 (H1). There is a positive association between the level of IR adoption and firm value.

In the next section, the method used for examining this relationship is described.

\section{Research Method}

This section describes the sample of the study, and the data and method used in the study.

\subsection{Sample}

The sample for the study was drawn from 83 companies (We individually checked the annual reports of all listed companies in different industry sectors $(n=298)$ of the CSE as of 31 December 2018 and followed a similar approach to that of Gunarathne and Senaratne [11] in deciding the companies that have prepared integrated reports complaint with IIRF) that had been listed in the Colombo Stock Exchange (CSE) and prepared integrated reports as of 31 December 2018. Out of these, we considered the companies that had prepared integrated reports for three consecutive years from 2015/2016 to 2017/2018. Though 57 companies had satisfied this requirement, the financial year of 18 companies ended on 31 December, and of the remaining 39 companies on 31 March. Hence, 39 companies whose financial year ended on March 31 were considered the sample for this study, similar to the approach of Cortesi and Vena [10] (see Table 3 for more details of these companies), and 117 integrated reports for the three-year period of these companies were examined.

The sample selected represents $68 \%$ of the companies that have prepared integrated reports during the three consecutive years considered in the study, and $47 \%$ of the IR adopters in Sri Lanka. Furthermore, the sample selected represents over $80 \%$ of the companies engaging in IR in every industrial sector of the CSE. Besides, as Sri Lanka has experienced an increase in the number of IR adopters since 2015, the selected sample represents the companies that have engaged in IR for a considerable period of time that warrants a proper assessment as to the adoption of IIRF as found in Herath et al. [12].

\subsection{Level of Adoption of IIRF in IR}

The extent of adoption of IIRF in IR was assessed through the content analysis of the selected 117 integrated reports using a comprehensive disclosure checklist based on IIRF. This checklist was initially developed by Herath and Gunarathne [62] based on the checklist of Stent and Dowler [17]. However, since there were some gaps related to the coverage of content elements and measurement scale, in this study, it was further improved by incorporating some features of the index developed by Kiliç and Kuzey [18]. Specifically, this checklist was used to examine the extent of adoption of the 38 disclosure items classified under the eight content elements of IIRF. A non-weighted disclosure approach was used, and each company received a score ranging from 0 to 74 , depending on the level of disclosure 
(see Appendix A). The multiple trained raters' method was used to eliminate subjectivity and improve the accuracy of assessing compliance with IIRF while ensuring inter-rater reliability [63]. Using the disclosure checklist, the total IR score and the score for each content element were calculated for each company, and the coverage of content elements of IIRF was analyzed using descriptive statistics.

Table 3. Sample companies.

\begin{tabular}{|c|c|c|c|}
\hline Industry Sector & No. of Companies & Company Name & $\begin{array}{l}\text { Market Capitalization (Rs. } \\
\text { Million) as at } 31 \text { March } 2019\end{array}$ \\
\hline \multirow{8}{*}{ Finance } & \multirow{8}{*}{7} & Alliance Finance Company PLC & 1806.11 \\
\hline & & Arpico Finance Company PLC & 1145.38 \\
\hline & & Citizens Development Business & \\
\hline & & Finance PLC & 3569.67 \\
\hline & & L B Finance PLC & $16,772.14$ \\
\hline & & Mercantile Investments \& Finance PLC & 7756.38 \\
\hline & & People's Leasing \& Finance PLC & $21,170.16$ \\
\hline & & Softlogic Finance PLC & $11,812.50$ \\
\hline \multirow{6}{*}{$\begin{array}{c}\text { Beverage, Food } \\
\text { and Tobacco }\end{array}$} & \multirow{6}{*}{6} & Cargills (Ceylon) PLC & $51,199.99$ \\
\hline & & Ceylon Cold Stores PLC & $54,648.00$ \\
\hline & & Keells Food Products PLC & 3182.40 \\
\hline & & Tea Smallholder Factories PLC & 723.00 \\
\hline & & Access Engineering PLC & $13,000.00$ \\
\hline & & MTD Walkers PLC & 2481.18 \\
\hline \multirow{6}{*}{$\begin{array}{l}\text { Diversified } \\
\text { Holdings }\end{array}$} & \multirow{6}{*}{6} & Aitken Spence PLC & $16,645.84$ \\
\hline & & Expolanka Holdings PLC & 7819.66 \\
\hline & & Hayleys PLC & $12,600.00$ \\
\hline & & John Keells Holdings PLC & $205,634.15$ \\
\hline & & Sunshine Holdings PLC & 7029.04 \\
\hline & & Vallibel One PLC & $15,537.80$ \\
\hline $\begin{array}{l}\text { Footwear and } \\
\text { Textiles }\end{array}$ & 1 & Hayleys Fabric PLC & 1765.80 \\
\hline \multirow{2}{*}{ Health Care } & \multirow{2}{*}{2} & Asiri Hospital Holdings PLC & $22,978.18$ \\
\hline & & Nawaloka Hospitals PLC & 5919.92 \\
\hline \multirow{3}{*}{ Hotels and Travels } & \multirow{3}{*}{3} & Aitken Spence Hotel Holdings PLC & 7970.07 \\
\hline & & John Keells Hotels PLC & $10,921.10$ \\
\hline & & The Lighthouse Hotel PLC & 1177.60 \\
\hline \multirow{4}{*}{ Manufacturing } & \multirow{4}{*}{4} & Alumex PLC & 2993.03 \\
\hline & & Dipped Products PLC & 4669.20 \\
\hline & & Lanka Tiles PLC & 3713.53 \\
\hline & & Teejay Lanka PLC & $21,339.48$ \\
\hline Motors & 1 & Diesel \& Motor Engineering PLC & 2704.65 \\
\hline \multirow{4}{*}{ Plantations } & \multirow{4}{*}{4} & Kelani Valley Plantations PLC & 3162.00 \\
\hline & & Maskeliya Plantations PLC & 582.70 \\
\hline & & Talawakelle Tea Estates PLC & 1156.63 \\
\hline & & Watawala Plantations PLC & 3717.81 \\
\hline \multirow{3}{*}{ Power and Energy } & \multirow{3}{*}{3} & Lanka IOC PLC & 9264.90 \\
\hline & & Laugfs Gas PLC & 5628.00 \\
\hline & & Resus Energy PLC & 705.37 \\
\hline $\begin{array}{l}\text { Supplies and } \\
\text { Stores }\end{array}$ & 1 & John Keells PLC & 2918.40 \\
\hline Trading & 1 & Brown \& Company PLC & $10,206.00$ \\
\hline
\end{tabular}

\subsection{Relationship between the Extent of Adoption of IIRF in IR and Value Relevance of IR}

This relationship was explored using regression analysis with the following two models: 
Model 01: Price Model

$$
\begin{aligned}
P_{i t}=\beta_{0} & +\beta_{1} E P S_{i t}+\beta_{2} B V S_{i t}+\beta_{3} I R S_{i t}+\beta_{4} E P S_{i t} * I R S_{i t} \\
& +\beta_{5} B V S_{i t} * I R S_{i t}+\beta_{6} \text { Size }_{i t}+\beta_{7} \text { Loss }_{i t} * E P S_{i t} \\
& +\varepsilon_{i t}
\end{aligned}
$$

$\begin{array}{ll}P_{i t} & \text { stock price per share for firm } i \text { at time } t, \text { six months after } \\ E P S_{i t} & \text { the fiscal year-end of time } t . \\ B V S_{i t} & \text { the earnings per share of firm } i \text { at time } t . \\ I R S_{i t} & \text { the book value per share of firm } i \text { at time } t . \\ S i z e_{i t} & \text { the IR score of firm } i . \\ \text { Loss }_{i t} & \text { the natural logarithm of total assets of firm } i \text { at time } t . \\ & \text { dummy variable that equals } 1 \text { if the firm achieves } \\ \text { negative earnings and } 0 \text { otherwise. }\end{array}$

Model 02: Return Model

$$
\begin{aligned}
& R_{i t}=\beta_{0}+\beta_{1} \frac{E P S_{i t}}{P_{i t}-1}+\beta_{2} \frac{\Delta E P S_{i t}}{P_{i t}-1}+\beta_{3} I R S_{i t}+\beta_{4} \frac{E P S_{i t}}{P_{i t}-1} \\
& * I R S_{i t}+\beta_{5} \frac{\Delta E P S_{i t}}{P_{i t-1}} * I R S_{i t}+\beta_{6} \text { Size }_{i t} \\
& +\beta_{7} \text { Loss }_{i t} * E P S_{i t}+\varepsilon_{i t}
\end{aligned}
$$

The first regression model analyzed the relationship between market price and level of adoption of IIRF in IR (price model), and the second regression model the relationship between market return and level of adoption of IIRF in IR (return model). Price and returns models [32] were extended in the study to reflect the effect of the level of IR on firm value in line with studies examining the value relevance of voluntary disclosures [64]. The share price and share returns were considered on 30 September after the expiry period of six months (As per CSE regulations, all listed companies required to issue their annual reports before expiration of five months from the year end. Hence, after considering the time period taken by each company in the sample to issue their annual reports (in which integrated report is embedded), it was decided to consider six-months as a reasonable period for the investors to recognize the value of IR) from the year-end (i.e., $31 \mathrm{March}$ ) as it will take a considerable time for the market to recognize the value of IR. In both the regression models, similar to that of other value relevance studies, this study used firm size and profitability as control variables $[7,10,43]$.

The data analysis performed in the study using the method described above is presented in the next section. 


\section{Analysis}

This section presents the findings of the study under two broad headings: First, the level of adoption of IIRF in IR is presented in terms of descriptive statistics, and second, its impact on the value relevance of IR is discussed in terms of correlation and regression analysis.

\subsection{Descriptive Statistics}

The level of adoption of IIRF in IR is assessed in terms of descriptive statistics for the disclosure scores (IRS) computed based on the IR index developed in the study. This analysis was carried out for 117 integrated reports prepared during the three-year period by the sample companies. The mean IRS increased from 45.13 to 52.74 between 2015/16 to 2017/2018, which shows a steady increase in the level of adoption of IIRF by the sample companies in the preparation of integrated reports. This is also supported by the gradual reduction in the standard deviation of mean IRS and the gap between maximum and minimum IRS of companies (see Table 4).

Table 4. Descriptive statistics—integrated reporting score (IRS).

\begin{tabular}{ccccccc}
\hline Year & N & Minimum & Maximum & Mean & Std. Deviation & Skewness \\
\hline $16 / 2015$ & 39 & 18 & 61 & 45.13 & 9.88 & -0.708 \\
$17 / 2016$ & 39 & 32 & 66 & 49.56 & 8.25 & -0.407 \\
$18 / 2017$ & 39 & 36 & 68 & 52.74 & 7.67 & -0.332 \\
\hline
\end{tabular}

Despite the increasing trend toward adoption, the relatively high standard deviation indicates a considerable variation in the disclosure scores of individual companies. This can be attributed to the voluntary nature of IR in the Sri Lankan context, which gives significant discretion to management to decide on the disclosures to be provided in an integrated report. The individual scores of the content elements of integrated reports provided in Table 5 show a variation in the coverage of disclosures of the sample companies under each content element of IIRF. A high level of coverage was observed in all three years in the content elements 'Organizational Overview and External Environment,' 'Governance,' 'Basis of Preparation and Presentation,' and 'Outlook'. The most encouraging feature is that the disclosure score of the 'Business Model' had increased substantially, and its rank order from 7 to 4 . The disclosure scores of 'Risk and Opportunities' and 'Performance' had also increased significantly, but their rank order had dropped over time by one level. Although the disclosure score had increased over time for 'Strategy and Resource Allocation,' it remained at the eighth place during the sample period. The ranking of scores of individual content elements had changed during the period under consideration based on the extent of coverage in each year (see Table 5).

\subsection{Correlation Analysis}

Tables 6 and 7 present the results of Pearson's product-moment correlation coefficient analysis conducted for the price model and the return model, respectively. The correlation analysis results of the price model indicate that earnings per share (EPS), book value per share (BVS), and firm size showed a statistically significant relationship $(p<0.01)$ with the price per share six months after the fiscal year-end. Specifically, EPS had a correlation coefficient of 0.811 , and BVS, a correlation coefficient of 0.928 , which indicates a strong positive relationship with price per share six-months after the fiscal year-end. However, firm size was seen to have a correlation coefficient of 0.240 , indicating a weak positive correlation. IRS and profitability did not show a systematic relationship with price per share six months after the fiscal year-end. According to Table 7, the independent variables $E P S_{i t} / P_{i t-1}$ and $\triangle E P S_{i t} / P_{i t-1}$ share a statistically significant relationship $(p<0.1$ and $p<0.01$, respectively) with stock returns. Its correlation coefficient signifies a moderate positive relationship. Furthermore, IRS showed an insignificant negative relationship with stock returns. The two control variables also did not show any significant association with the dependent variable. 
Table 5. Coverage of content elements.

\begin{tabular}{|c|c|c|c|c|c|c|c|c|c|c|c|c|}
\hline \multirow[b]{3}{*}{ IR Categories } & \multicolumn{12}{|c|}{ Score } \\
\hline & \multicolumn{4}{|c|}{2016} & \multicolumn{4}{|c|}{2017} & \multicolumn{4}{|c|}{2018} \\
\hline & Max*. & Actual & $\%$ & Rank & Max*. & Actual & $\%$ & Rank & Max*. & Actual & $\%$ & Rank \\
\hline $\begin{array}{l}\text { Organizational overview } \\
\text { and external environment }\end{array}$ & 624 & 424 & 68 & 4 & 624 & 456 & 73 & 3 & 624 & 480 & 77 & 3 \\
\hline Governance & 468 & 374 & 80 & 1 & 468 & 388 & 83 & 2 & 468 & 407 & 87 & 2 \\
\hline Business model & 390 & 187 & 48 & 7 & 390 & 265 & 68 & 5 & 390 & 297 & 76 & 4 \\
\hline Risks and opportunities & 312 & 153 & 49 & 6 & 312 & 162 & 52 & 7 & 312 & 175 & 56 & 7 \\
\hline $\begin{array}{c}\text { Strategy and resource } \\
\text { allocation }\end{array}$ & 234 & 77 & 33 & 8 & 234 & 84 & 36 & 8 & 234 & 96 & 41 & 8 \\
\hline Performance & 507 & 299 & 59 & 5 & 507 & 330 & 65 & 6 & 507 & 340 & 67 & 6 \\
\hline Outlook & 156 & 107 & 69 & 3 & 156 & 108 & 69 & 4 & 156 & 111 & 71 & 5 \\
\hline Basis of preparation & 195 & 144 & 74 & 2 & 195 & 168 & 86 & 1 & 195 & 172 & 88 & 1 \\
\hline Overall results & 2886 & 1765 & 61 & & 2886 & 1961 & 68 & & 2886 & 2078 & 72 & \\
\hline
\end{tabular}

Note: ${ }^{*}$ Maximum Score $=$ Maximum score of each content element ${ }^{*} 39$ companies 
Table 6. Correlation analysis-price model.

\begin{tabular}{|c|c|c|c|c|c|c|c|}
\hline \multicolumn{2}{|c|}{ Variables } & 1 & 2 & 3 & 4 & 5 & 6 \\
\hline 1 & $P_{i t}$ & 1.000 & & & & & \\
\hline 2 & $E P S_{i t}$ & $0.811^{* * *}$ & 1.000 & & & & \\
\hline 3 & $B V S_{i t}$ & $0.928^{* * *}$ & $0.854^{* * *}$ & 1.000 & & & \\
\hline 4 & $I R S_{i t}$ & 0.038 & 0.104 & 0.084 & 1.000 & & \\
\hline 5 & Size $_{i t}$ & $0.240^{* * *}$ & $0.210 * *$ & $0.232 * *$ & $0.192 * *$ & 1.000 & \\
\hline 6 & $\operatorname{Loss}_{i t}$ & -0.097 & $-0.194^{* *}$ & -0.088 & -0.160 * & -0.173 * & 1.000 \\
\hline
\end{tabular}

Table 7. Correlation analysis-return model.

\begin{tabular}{|c|c|c|c|c|c|c|c|}
\hline \multicolumn{2}{|c|}{ Variables } & 1 & 2 & 3 & 4 & 5 & 6 \\
\hline 1 & $\boldsymbol{R}_{i t}$ & 1.000 & & & & & \\
\hline 2 & $E P S_{i t} / P_{i t-1}$ & $0.159 *$ & 1.000 & & & & \\
\hline 3 & $\Delta E P S_{i t} / P_{i t-1}$ & $0.537^{* * *}$ & $0.554^{* * *}$ & 1.000 & & & \\
\hline 4 & $I R S_{i t}$ & -0.073 & $0.245^{* * *}$ & 0.012 & 1.000 & & \\
\hline 5 & Size $_{i t}$ & -0.016 & 0.018 & -0.053 & $0.192 * *$ & 1.000 & \\
\hline 6 & $\operatorname{Loss}_{i t}$ & 0.042 & $-0.579^{* * *}$ & $-0.277^{* * *}$ & -0.160 * & -0.173 * & 1.000 \\
\hline
\end{tabular}

\subsection{Regression Analysis}

Table 8 presents the results of the Ordinary Least Squares (OLS) multivariate regression analysis of the price model with the level of significance indicated at 99 percent, 95 percent, and 90 percent, respectively. Prior to the regression analysis, the regression assumptions were checked, and it was revealed that autocorrelation exists with the model. In order to rectify this issue, the Prais-Winsten estimation method was used as described in Judge et al. [65]. Accordingly, the new Durbin-Watson value 1.812 , which is approximately 2 , indicates that the model is not suffering from autocorrelation [66]. Further, $\mathrm{R}^{2}$ shows that 92.2 percent of the market price is explained by the independent variables, and the $\mathrm{F}$ value is 189.82 . This model is significant, as the $p$-value is $0.000(p<0.05)$. Surprisingly, the estimated coefficient of EPS indicates a statistically significant $(p<0.01)$ negative association with the market price, which hints at the impact of country specific macroeconomic factors on the stock market performance [67] (The performance of the CSE indices continued to deteriorate due to the depressed economic activities, political instability, subpar performance of corporate sector, and the significant depreciation of the rupee against major currencies during the selected time period of this study [68]). However, BVS has shown a significant positive relationship with market price, which depicts a positive coefficient of 2.759. This suggests that only the book values reported by the firms in the sample have played an important role in the equity valuation. 
Table 8. OLS multivariate regression analysis-price model.

\begin{tabular}{|c|c|c|}
\hline Model & Coef. & $\mathbf{t}$ \\
\hline Intercept & -43.458 & -0.397 \\
\hline$E P S_{i t}$ & -12.362 & $-3.831^{* * *}$ \\
\hline$B V S_{i t}$ & 2.759 & $10.369 * * *$ \\
\hline$I R S_{i t}$ & 0.436 & 0.372 \\
\hline$E P S_{i t} * I R S_{i t}$ & 0.251 & $3.627^{* * *}$ \\
\hline$B V S_{i t} * I R S_{i t}$ & -0.04 & $-7.346^{* * *}$ \\
\hline Size $_{i t}$ & 2.043 & 0.473 \\
\hline $\operatorname{Loss}_{i t} * E P S_{i t}$ & -2.906 & -0.809 \\
\hline F-value & 189.82 & \\
\hline Sig. of F-value & 0.000 & \\
\hline $\mathrm{R}^{*}$ & 0.922 & \\
\hline $\mathrm{N}$ & 117 & \\
\hline
\end{tabular}

IRS, in isolation, did not depict a significant association with firm value. However, the results have shown that the coefficients of the interaction between accounting constructs and IR disclosure construct ( $\beta 4$ and $\beta 5$ ) are statistically significant. For coefficient $\beta 4$ (EPS*IRS), the results indicate a positive association, implying a significant positive influence of IRS compliant with IIRF on the value relevance of earnings. On the contrary, coefficient $\beta 5$ (BVS*IRS) has shown a significant negative relationship between the value relevance of book value and the level of IRS. The results further emphasize that the control variable, the firm size, did not significantly relate to the firm value. Besides, the results reveal that the coefficient estimate of the profitability variable (LOSS*EPS) is negative but insignificant, suggesting that the value relevance was lower for loss-making firms than for profit-making firms.

Table 9 presents the OLS multivariate regression results of the return model. The model has significant explanatory power for stock returns $\left(\mathrm{R}^{2}=36.1 \%, \mathrm{~F}=8.803, p<0.01\right)$. It is important to notice the lower level of $R^{2}$ value, which is a consequence of 'accounting recognition lag,' as mentioned in the literature review section. Accounting recognition lag is an inherent weakness of the return model where the value relevant events observed by the market in the current period and reflected in current returns may not be recorded in the same period's earnings, due to the accounting principles such as reliability and prudence [13]. Similarly, Sutopo et al. [69], Easton et al. [70], and Kothari and Zimmerman [71] have reported $R^{2}$ values that are less than $40 \%$ for the return model. Further, the estimated coefficient of $\beta 1$ is surprisingly negatively related with firm value. However, it is statistically significant $(p<0.10)$. This result confirmed the findings of the price model that even though the earnings level is a significant factor, it is negatively associated with the firms' valuation. In contrast, an insignificant positive association was observed in earnings changes ( $\beta 2)$. This insignificant result suggests that investors had a very short-term prospect, as they focused heavily on concurrent earnings (earnings levels) rather than on changes in earnings.

The coefficient of the interaction of earnings and IR disclosures ( $\beta 4)$ is positive and significant, which indicates the positive influence of the IR disclosures on the value relevance of earnings. Nevertheless, the coefficient of interaction of changes in earnings and IR disclosures is negative and insignificant. Furthermore, none of the control variables had a statistically significant relationship with stock returns.

Overall, the findings of the study indicate that the level of compliance of IRS with IIRF has increased over time. However, this increase has not significantly impacted firm value under both price model and return model. Nevertheless, IRS has a positive and statistically significant relationship on firm value when combined with the information on EPS. Hence, when IRS is considered with the accounting information of companies, it shows a positive impact on firm value, indicating that the value relevance of accounting information has increased under IR. 
Table 9. OLS multivariate regression analysis—return model.

\begin{tabular}{|c|c|c|}
\hline Model & Coef. & $\mathbf{t}$ \\
\hline Intercept & 0.067 & 0.275 \\
\hline$E P S_{i t} / P_{i t-1}$ & -2.253 & $-1.871 *$ \\
\hline$\Delta E P S_{i t} / P_{i t-1}$ & 1.737 & 1.145 \\
\hline$I R S_{i t}$ & -0.006 & -1.612 \\
\hline$E P S_{i t} / P_{i t-1} * I R S_{i t}$ & 0.045 & $1.652 *$ \\
\hline$\Delta E P S_{i t} / P_{i t-1} * I R S_{i t}$ & -0.007 & -0.209 \\
\hline Size $_{i t}$ & 0.006 & 0.677 \\
\hline $\operatorname{Loss}_{i t} * E P S_{i t}$ & -0.003 & 1.369 \\
\hline F-value & 8.803 & \\
\hline Sig. of F-value & 0.000 & \\
\hline $\mathrm{R}^{2}$ & 0.361 & \\
\hline $\mathrm{N}$ & 117 & \\
\hline
\end{tabular}

\section{Discussion}

The above analysis leads to several important points for discussion.

First, concerning the extent of adoption of IIRF in IR, the study found that the Sri-Lankan-listed companies show a significant improvement over time, which is in line with other countries or regions such as Netherlands, South Africa, and the UK [1-3,7]. The study extends this analysis by showing how the Sri-Lankan companies have improved their integrated reports in terms of individual content elements of IIRF. This worldwide increase in the adoption of IIRF has resulted in companies developing understanding and competence in respect of the requirements of IIRF $[2,3,18]$ and regulatory and capital market support extended to develop IIRF-complaint IR [7,8]. With the adoption of IR, the benefits resulting from the process, such as the development of integrated thinking, enhanced stakeholder engagement, increased focus on material issues, and encouragement for companies to focus on strategy and achieve conciseness, had also acted as drivers of IR [1]. In addition to this global situation, in the Sri-Lankan context, this increasing trend can be specifically attributed to the active propagation of IR through awareness and training programs on IR conducted for companies by professional accounting bodies (PABs) and business schools, the support services provided by consultancy firms and annual report preparation companies, and excellence in IR awards conducted by PABs [11]. These external factors have created the necessary setting for Sri-Lankan companies to engage in IR.

Second, this study found that the increased adoption of IIRF in IR in Sri-Lankan companies did not have a significant impact on firm value, as hypothesized in the study. This is contrary to the findings of the extant literature $[7,9,10,41,42]$. However, this study differs from all these studies except those of Cortesi and Vena [10] and Loprevite et al. [42], as they have considered this relationship in South Africa, where IR is a mandatory exercise. Further, Cortesi and Vena [10] and Loprevite et al. [42] do not confine their study to a particular country context. Cortesi and Vena [10] used a large sample study covering several countries, where IR adoption is a voluntary exercise. On the other hand, Loprevite et al. [42] focused on IR-adopting companies and non-adopters in the European Union. Hence, the differences in the contextual setting (i.e., the mandatory nature of IR in South Africa in the studies of Lee and Yeo [7], Zhou et al. [9], and Cosma et al. [40]) and the number of observations in the study of Cortesi and Vena [10] and Loprevite et al. [42] seem to have a bearing on the findings of this study. Further, IR not being able to impact significantly on the firm value of Sri-Lankan companies may have resulted from the adoption of IR as a fashionable choice by a significant number of late adopters who joined the IR bandwagon [11]. This suggests that despite the heavy propagation of IR by many actors in the Sri-Lankan accounting profession such as PABs, business schools, and support service providers, the majority of companies have not realized the benefits of IR that is accentuated through integrated thinking. 
These findings indicate that investors have not found IR useful to the extent IIRC expects so as to benefit the providers of capital. In this respect, ACCA [72] found several barriers to capital market penetration of IR from a demand perspective covering providers of financial capital and other financial users in the UK, Europe, North America, Asia, and developing and emerging markets. These include the lack of penetration of IR in the capital market due to a lack of familiarity with investors in general, concerns that some investors raised as to the measurability and connectivity of the capital market model, and the lack of widespread engagement and discourse with investors as to IR through capital market events such as the issuance of quarterly reports. This study also highlighted that while the increased number of integrated reports has helped to achieve a 'critical mass,' the more demanding challenge for its penetration in the capital market is the lack of a supportive culture within the equity market in this respect and the incentive-led demand for equity analysts. Though this study has not explicitly explored the Sri-Lankan capital market, the findings of the study would stand in good stead in the local context as well.

Moreover, these findings do not support the proposition in the enlightened stakeholder theory of Jensen [15]. Due to the reasons explained above, in the Sri-Lankan context, the value creation of firms has not been translated into the total long-term market value of a firm. Hence, the effective management of stakeholder relationships through six capitals has not led to an increase in the stock market performance of the Sri-Lankan firms. Perhaps, the Sri-Lankan firms have taken steps to utilize firms' capitals (or resources) without considering the marginal benefits of such activities.

On the other hand, the findings of the current study could have a bearing on the research that criticizes the role of IR. For example, Flower [53] argued that the IIRC's concept of value is 'value for investors' and not 'value for society', and that it places no obligation on firms to report the harm inflicted on entities outside the firm (such as the environment and society), where there is no subsequent impact on the firm. This validates the argument put forward by Jensen [15] that the corporate objective function should capture the long-term value generated to shareholders, which encompasses the expectations of other stakeholders as well. This argument presented as the enlightened stakeholder theory by Jensen [15] was supported lately by the studies of Margolis and Walsh [49], Queen [60], and Cook et al. [48], which show the importance to companies of focusing on long-term value creation by a firm.

Nevertheless, the study found a statistically significant positive relationship between the level of IR based on IIRF and the firm value when the level of IR is considered in combination with EPS. These results are in line with the expectation of IIRC [24] that the value relevance of accounting information improved with IR as it combines financial information with the environmental, social, and governance (ESG) information of firms, which were previously disconnected to a large extent. This expectation is empirically supported by the findings of Baboukardos and Rimmel [8] and Cortesi and Vena [10], who found that the value relevance of EPS increased with the adoption of IR by companies. Further, Loprevite et al. [42] found that the value relevance of accounting information is higher in IR-adopting companies compared to the non-adopters in the European Union. Thus, this study shows that through the improvements made to accounting information, IR contributes to improving the firm value of Sri-Lankan companies in line with prior studies.

The present study also shows that the level of IR, when combined with BVS, has a significant negative impact on firm value in line with the findings of Baboukardos and Rimmel [8] and Cortesi and Vena [10]. Prior studies attributed this decline to the equal importance that IIRC [24] attached to multiple sources of capital, which reduced the significance of financial capital devoted by BVS [8]. IIRC [24] emphasizes that there are critical interdependencies and tradeoffs among the six capitals when creating value for an organization. Accordingly, in the process of value creation, investments or an increase in one capital could occur at the expense another capital, such as financial capital. This could result in such a negative interaction similar to the one as portrayed in our study. Thus, the study confirms that IR has been able to improve EPS in the context of an emerging market in 
South Asia, indicating that the value of information disclosed to the capital market through financial statements reflects an improvement following the adoption of IR.

\section{Conclusions}

This study examined the relationship between the intensity of IR based on the extent of adoption of IIRF and the value relevance of information disclosed in the integrated reports in Sri Lanka. Having developed a detailed disclosure index based on IIRF, 117 integrated reports were content-analyzed to assess the extent of adoption of IIRF in IR. The association between the level of IR in terms of IIRF and the firm value (a proxy for value relevance) was analyzed using both price and return models extended to reflect the impact of IR on firm value. Despite the increasing trend in the adoption of IIRF in the preparation of integrated reports, this study found that it had not significantly impacted the firm value in isolation. Instead, it showed a significant positive association with the firm value when considered in combination with accounting earnings information.

The findings of this study have several implications for theory and practice. For theory, this study suggests the potential of considering various other proxy measures, as outlined in Table 2, in measuring the value relevance of IR information. It will be insightful to use a range of possible proxy measures in a single study to identify how the value relevance of IR varies, and any underlying reasons for such differences. Since the value of information reported in integrated reports largely depends on the nature of the capital markets, it will also be useful to analyze this relationship in different types of capital markets in developed countries against the emerging economies. Further, in this study, in measuring the IR score, a checklist was developed based on content elements. As different scholars have suggested various other methods of measuring the level of IR adoption, it will also be interesting to use these measures to check how the relationship between the level of IR and the firm value changes. Furthermore, this study can be extended to assess the investors' perception of the information presented in an integrated report, as their perceptions will provide a basis for responses made towards the information disclosed.

For practice, this study has several implications. First, for policymakers and regulators, it highlights the importance of improving IR as a tool to enhance the value relevance of accounting information reported by companies for capital market development. While this is a positive impact, it also highlights that more policy initiatives needed to improve the penetration of IR in the capital market in terms of enhancing the awareness of investors as well as of equity analysts, and bringing IR information to the forefront of the corporate reporting guidelines of the Securities and Exchange Commission and CSE.

Second, the study points to the possibility of companies practicing IR to understand the benefits that they can gain through the adoption of IIRF compliance IR by way of improving the quality and reliability of accounting information. At the same time, it underscores the need for more corporate level initiatives to improve the level of penetration of IR disclosures in the capital market. In this respect, the companies can make IR disclosures a regular feature of their internal corporate communications, company websites, and press releases.

Third, through the findings of the study, standard setters such as IIRC and PABs can identify the extent to which IR can achieve their expectations in meeting the needs of investors and other financial capital providers on the value creation of firms from a broad perspective. In this respect, both IIRC and PABs can facilitate the policy initiatives of countries for strengthening IR penetration in capital markets and building a supportive capital market culture in this respect.

Fourth, this study shows how investors can understand the mechanism through which a new reporting model, such as IR, improves the value relevance of corporate disclosures in facilitating their decision-making process. These findings thus shed light on the importance of combining both financial and ESG information when decisions are made by investors to invest, hold, or divest their funds in a particular organization.

The findings of the study on the value relevance of IR will lead managers to integrate shareholder wealth maximization and stakeholder management motivated by long-term value creation for 
shareholders, as suggested in the enlightened stakeholder theory proposed by Jensen in 2001 [49,60]. This would enable Sri-Lankan companies to avoid focusing on short-term financial performance at the expense of long-term value creation for shareholders [48]. Thus, as argued in the enlightened stakeholder theory, IR-compliant IR would cause the much-needed integration of strategy, governance, performance, and prospects focusing on long-term value creation for providers of capital as expected by IIRC [24].

While we believe that our findings offer useful insights into the value relevance of IR in a developing country context, we recognize that our analysis is limited in at least three ways. First, the main limitation is its small sample of 39 companies, thereby limiting the number of observations to 117 integrated reports for the three-year period considered. Second, the study is limited to a single country and a specific period during which the Sri-Lankan economy and stock market operations were at a declining stage. Further, Sri Lanka has a progressive accounting profession that has been keen to adopt new developments in accounting such as sustainability reporting and IR $[16,73,74]$. These factors could have an impact on the outcome of the study. Hence, in future studies, it is recommended that a larger sample be used, if possible, covering several countries in a particular region that share similar institutional settings and contextual factors. Third, the study considered only the impact of the overall IR disclosure score on firm value. However, had the relationship of individual content elements scores on firm value been analyzed, more meaningful information would have been revealed. Hence, it is also recommended that the impact caused by each content element on firm value is analyzed in future studies.

Author Contributions: Writing—original draft, T.C., S.S., A.D.N.G., R.H., and D.S. All authors have read and agreed to the published version of the manuscript.

Funding: This research was supported by the Accelerating Higher Education Expansion and Development (AHEAD) Operation of the Ministry of Higher Education, Sri Lanka, funded by the World Bank.

Conflicts of Interest: The authors declare no conflict of interest.

Appendix A. IR Index of the Study

Table A1. Summarised Index.

\begin{tabular}{ccc}
\hline Content Element & No. of Disclosure Items & Score \\
\hline Organizational overview and external environment & 7 & 16 \\
Governance & 7 & 12 \\
Business model & 5 & 10 \\
Risk and opportunities & 3 & 8 \\
Strategy and resource allocation & 4 & 6 \\
Performance & 6 & 13 \\
Outlook & 3 & 4 \\
Basis of preparation and presentation & 3 & 5 \\
Total & 38 & 74 \\
\hline
\end{tabular}


Table A2. Detailed Index.

\begin{tabular}{|c|c|c|c|}
\hline m Content Element & Disclosure Item & Marking Guidelines & Score \\
\hline \multirow{8}{*}{$\begin{array}{l}\text { Organizational } \\
\text { overview and } \\
\text { external environment }\end{array}$} & 1) Vision and mission & $1=$ Vision $; 1=$ Mission & 2 \\
\hline & 2) Value, ethics, and culture & $\begin{array}{l}0=\text { Not disclosed; } 1=\text { General comments on } \\
\text { adherence to ethical values mentioned; } 2 \text { = Code } \\
\text { of conduct reference, list of values, etc., provided. }\end{array}$ & 2 \\
\hline & 3) Ownership and operating structure & $\begin{array}{l}0=\text { Not disclosed; } 1=\text { Ownership and operating } \\
\text { structure described. }\end{array}$ & 1 \\
\hline & 4) Principal activities, markets, products, services & $\begin{array}{l}0=\text { No specifics on principal activities disclosed; } 1 \\
=\text { Activities/markets/products services listed }\end{array}$ & 1 \\
\hline & $\begin{array}{l}\text { 5) Competitive landscape, market positioning, and } \\
\text { positioning within the value chain }\end{array}$ & 1 mark for each. & 3 \\
\hline & 6) Key quantitative information & $\begin{array}{l}\text { [Employees, revenues, locations and changes] } \\
1=1-2 \text { elements; } 2=3-4 \text { elements. }\end{array}$ & 2 \\
\hline & $\begin{array}{l}\text { 7) Significant factors affecting external environment } \\
\text { and the organization's response }\end{array}$ & $\begin{array}{l}\text { [Legal, commercial, social, environmental, } \\
\text { political] maximum of } 5 \text { points, } 1 \text { for each context. }\end{array}$ & 5 \\
\hline & Sub-score & & 16 \\
\hline \multirow{4}{*}{ Governance } & $\begin{array}{l}\text { 1) Leadership structure, diversity, and skill set of } \\
\text { those charged with governance }\end{array}$ & $\begin{array}{l}1=\text { Members of the BoD listed; } \\
2=\text { Their experience and skills are listed as well. }\end{array}$ & 2 \\
\hline & $\begin{array}{l}\text { 2) Processes used to make strategic decisions and } \\
\text { monitor culture including its attitude to risk and } \\
\text { mechanisms for addressing integrity and ethical } \\
\text { issues }\end{array}$ & $\begin{array}{l}0=\text { Not explained; } 1=\text { Role of board/executive } \\
\text { committee in making strategic decisions explained; } \\
1=\text { Role of risk management committee in } \\
\text { monitoring the strategic direction explained. }\end{array}$ & 2 \\
\hline & $\begin{array}{l}\text { 3) Actions taken to monitor and influence strategic } \\
\text { direction and its approach to risk management }\end{array}$ & $\begin{array}{l}0=\text { No actions determinable; } 1=\text { Actions taken to } \\
\text { monitor the strategic direction is determinable; } \\
2=\text { Actions taken to manage risks is determinable. }\end{array}$ & 2 \\
\hline & $\begin{array}{l}\text { 4) Reflection of culture and ethical values in use of } \\
\text { and effect on the capitals, relationship with key } \\
\text { stakeholders }\end{array}$ & $\begin{array}{l}0=\text { No explanation of cultural values/ethics in the } \\
\text { given context; } 1=\text { Culture and values } \\
\text { determinable from narrative; } 2=\text { Culture and } \\
\text { values reflect in the use of and effects on } \\
\text { capitals/stakeholders. }\end{array}$ & 2 \\
\hline
\end{tabular}


Table A2. Cont.

\begin{tabular}{|c|c|c|c|}
\hline Content Element & Disclosure Item & Marking Guidelines & Score \\
\hline & $\begin{array}{l}\text { 5) Responsibility for promoting and enabling } \\
\text { innovation by governance agents }\end{array}$ & $\begin{array}{l}0=\text { No disclosure; } 1=\text { Responsibility for } \\
\text { promoting innovation is mentioned. }\end{array}$ & 1 \\
\hline & 6) Governance practices exceeds legal requirements & $0=$ No disclosure $; 1=$ Explanations provided & 1 \\
\hline & 7) Compensation policies and plans & $\begin{array}{l}1=\text { Compensation policies and plans are } \\
\text { determinable; } 2 \text { = Compensation policies and } \\
\text { plans are linked to the value creation. }\end{array}$ & 2 \\
\hline & Sub-score & & 12 \\
\hline \multirow{6}{*}{ Business model } & 1) Diagrammatic presentation & $0=$ No diagram $; 1=$ Diagram provided & 1 \\
\hline & 2) Key elements of the business model & $\begin{array}{l}1 \text { each for input, business activities, output and } \\
\text { outcome. }\end{array}$ & 4 \\
\hline & 3) Narrative flow based on the business model & $\begin{array}{l}0=\text { No explanation provided; } 1=\text { Good flow of } \\
\text { explanation provided. }\end{array}$ & 1 \\
\hline & $\begin{array}{l}\text { 4) Critical stakeholders' identification and other } \\
\text { dependencies }\end{array}$ & $\begin{array}{l}0=\text { No stakeholder engagement described; } 1= \\
\text { Explicit stakeholder engagement described. }\end{array}$ & 1 \\
\hline & $\begin{array}{l}\text { 5) Connection to information covered in other } \\
\text { content elements (e.g., strategy, risk, and } \\
\text { opportunities and performance) }\end{array}$ & $\begin{array}{l}0=\text { No connection provided; } 1=1-2 \text { aspects } \\
\text { described; } 2=3-4 \text { aspects described; } 3=\text { more } \\
\text { than } 4 \text { aspects described. }\end{array}$ & 3 \\
\hline & Sub-score & & 10 \\
\hline \multirow{4}{*}{ Risk and opportunities } & 1) Key risks and opportunities & $1=$ Risks described; 1 = Opportunities described & 2 \\
\hline & 2) Assessment of the likelihood and impact & $\begin{array}{l}1 \text { for each; explanation of the risk likelihood, } \\
\text { explanation of the opportunity likelihood, } \\
\text { magnitude of impact of risk and magnitude of } \\
\text { impact of opportunity }\end{array}$ & 4 \\
\hline & $\begin{array}{l}\text { 3) Steps to mitigate/manage risk or create value } \\
\text { from opportunity }\end{array}$ & $\begin{array}{l}1=\text { Steps to mitigate/manage risk provided; } 1= \\
\text { Steps to create value from opportunity provided. }\end{array}$ & 2 \\
\hline & Sub-score & & 8 \\
\hline
\end{tabular}


Table A2. Cont.

\begin{tabular}{|c|c|c|c|}
\hline Content Element & Disclosure Item & Marking Guidelines & Score \\
\hline \multirow{5}{*}{ Strategy and resource allocation } & 1) Short, medium, long term strategic objectives & $\begin{array}{l}0=\text { No description provided; } 1=\text { Strategic } \\
\text { objectives stated without relevant time frame; } 2= \\
\text { Strategic objectives and their time frames are } \\
\text { listed. }\end{array}$ & 2 \\
\hline & $\begin{array}{l}\text { 2) Strategies in place or plan to implement to } \\
\text { achieve the objectives }\end{array}$ & $\begin{array}{l}0=\text { No specific description provided; } 1=\text { Specific } \\
\text { actions taken/planned are described. }\end{array}$ & 1 \\
\hline & 3) Resource allocation plan to implement strategies & 0 = No plan explained; 1 = Plan explained. & 1 \\
\hline & $\begin{array}{l}\text { 4) Measurement of achievements and target } \\
\text { outcomes }\end{array}$ & $\begin{array}{l}0=\text { Not disclosed; } 1=\text { Measurement of } \\
\text { achievement of strategic objectives stated without } \\
\text { relevant time frame disclosed; } 2=\text { Measurement of } \\
\text { achievement of strategic objectives with their time } \\
\text { frames are listed. }\end{array}$ & 2 \\
\hline & Sub-score & & 6 \\
\hline \multirow{5}{*}{ Performance } & $\begin{array}{l}\text { 1) KPIs that draws relationship between financial } \\
\text { performance and performance regarding other } \\
\text { capitals }\end{array}$ & $\begin{array}{l}0=\text { No mixed KPIs or equivalent disclosed; } 1=\mathrm{A} \\
\text { mix of financial and other KPIs or equivalent } \\
\text { disclosed; } 2=\text { KPIs linking financial and other } \\
\text { capitals disclosed. }\end{array}$ & 2 \\
\hline & 2) KRIs & $\begin{array}{l}0=\text { No key risk indicators described; } 1=\text { KRIs or } \\
\text { equivalent described. }\end{array}$ & 1 \\
\hline & $\begin{array}{l}\text { 3) Explanation of KPIs and KRIs of significance, } \\
\text { implications and methods and assumptions used in } \\
\text { compiling them }\end{array}$ & $\begin{array}{l}1 \text { = Explanation of significance of KPIs and KRIs; } 1 \\
=\text { Implications of KPIs/KRIs; } 1 \text { = Methods and } \\
\text { assumptions used in compiling them explained. }\end{array}$ & 3 \\
\hline & 4) The organization's effect on the capitals & $\begin{array}{l}0=\text { No consideration to the six capitals; } 1= \\
\text { Consideration of financial and manufactured } \\
\text { capitals; } 2 \text { = All material capitals considered. }\end{array}$ & 2 \\
\hline & $\begin{array}{l}\text { 5) State of key stakeholder relationships and how } \\
\text { the organization has responded to key stakeholder } \\
\text { needs and interests }\end{array}$ & $\begin{array}{l}1=\text { Key stakeholder relationships stated; } 1= \\
\text { Identification of key stakeholder needs and } \\
\text { interests provided; } 1=\text { Organizational response to } \\
\text { key stakeholder needs and interests provided. }\end{array}$ & 3 \\
\hline
\end{tabular}


Table A2. Cont.

\begin{tabular}{|c|c|c|c|}
\hline Content Element & Disclosure Item & Marking Guidelines & Score \\
\hline & $\begin{array}{l}\text { 6) Comparison of past and present performance } \\
\text { and current performance and target performance }\end{array}$ & $\begin{array}{l}0=\text { No comparison provided; } 1=\text { Comparison of } \\
\text { past and present performance; } 2=\text { Comparison of } \\
\text { past and present performance and current } \\
\text { performance and target performance. }\end{array}$ & 2 \\
\hline & Sub-score & & 13 \\
\hline \multirow{4}{*}{ Outlook } & $\begin{array}{l}\text { 1) Management's expectations about external } \\
\text { environment }\end{array}$ & $\begin{array}{l}0=\text { No statement provided; } 1=\text { Expectations } \\
\text { described without timeframe; } 2=\text { Expectations } \\
\text { described with time frame. }\end{array}$ & 2 \\
\hline & $\begin{array}{l}\text { 2) Potential implications of these external } \\
\text { expectations on the organization }\end{array}$ & $0=$ Not explained $; 1=$ Implications explained. & 1 \\
\hline & $\begin{array}{l}\text { 3) Organizational readiness in responding to the } \\
\text { challenges and uncertainties }\end{array}$ & $0=$ Not explained $; 1=$ Readiness explained & 1 \\
\hline & Sub-score & & 4 \\
\hline \multirow{4}{*}{ Basis of preparation and presentation } & $\begin{array}{l}\text { Summary of materiality determination } \\
\text { process-Material issues/determination, impact on } \\
\text { creating/preserving value }\end{array}$ & $\begin{array}{l}0=\text { No discussion of material matters; } 1= \\
\text { Description of processes used to identify the } \\
\text { material matters; } 1=\text { Identification of the role of } \\
\text { key personnel in the identification and } \\
\text { prioritization of material matters } \\
\text { identification and prioritization of material issues }\end{array}$ & 2 \\
\hline & Reporting boundary and its determination & $\begin{array}{l}0=\text { No boundary disclosed; } 1=\text { Boundary is } \\
\text { determinable; } 2=\text { Boundary determinable and the } \\
\text { process explained. }\end{array}$ & 2 \\
\hline & $\begin{array}{l}\text { Summary of significant frameworks and methods } \\
\text { used to quantify or evaluate material matters }\end{array}$ & $\begin{array}{l}0=\text { No frameworks or method used; } \\
1=\text { Frameworks and methods used }\end{array}$ & 1 \\
\hline & Sub-score & & 5 \\
\hline Total Score & & & 74 \\
\hline
\end{tabular}




\section{References}

1. Deloitte. Integrated Reporting as a Driver for Integrated Thinking? 2015. Available online: https://www2.1.com/ content/dam/1/nl/Documents/risk/1-nl-risk-:integrated-reporting-a-driver-for-integrated-thinking.pdf (accessed on 18 June 2018).

2. Ahmed Haji, A.; Anifowose, M. The trend of integrated reporting practice in South Africa: Ceremonial or substantive. Sustain. Account. Manag. Policy J. 2016, 7, 190-224. [CrossRef]

3. Hassan, A.; Adhikariparajuli, M.; Fletcher, M.; Elamer, A. Integrated reporting in UK higher education institutions. Sustain. Account. Manag. Policy J. 2019, 10, 844-876. [CrossRef]

4. Cooray, T.; Gunarathne, A.D.; Senaratne, S. Does Corporate Governance Affect the Quality of Integrated Reporting? Sustainability 2020, 12, 4262. [CrossRef]

5. Wahl, A.; Charifzadeh, M.; Diefenbach, F. Voluntary Adopters of Integrated Reporting-Evidence on Forecast Accuracy and Firm Value. Bus. Strategy Environ. 2020, 29, 2542-2556. [CrossRef]

6. Muttakin, M.B.; Mihret, D.; Lemma, T.T.; Khan, A. Integrated reporting, financial reporting quality and cost of debt. Int. J. Account. Inf. Manag. 2020, 28, 517-534. [CrossRef]

7. Lee, K.W.; Yeo, G.H.H. The association between integrated reporting and firm valuation. Rev. Quant. Financ. Account. 2016, 47, 1221-1250. [CrossRef]

8. Baboukardos, D.; Rimmel, G. Value relevance of accounting information under an integrated reporting approach: A research note. J. Account. Public Policy 2016, 35, 437-452. [CrossRef]

9. Zhou, S.; Simnett, R.; Green, W. Does integrated reporting matter to the capital market? Abacus 2017, 53, 94-132. [CrossRef]

10. Cortesi, A.; Vena, L. Disclosure quality under integrated reporting: A value relevance approach. J. Clean. Prod. 2019, 220, 745-755. [CrossRef]

11. Gunarathne, N.; Senaratne, S. Diffusion of integrated reporting in an emerging South Asian (SAARC) nation. Manag. Audit. J. 2017, 32, 524-548. [CrossRef]

12. Herath, R.; Cooray, T.; Gunarathne, A.D.N.; Samudrage, D.; Senaratne, S.; Lee, K.H. The Adoption of Integrated Reporting Practice in Sri Lanka. In Proceedings of the Global Conference of Environmental and Sustainability Management Accounting Network (EMAN), Danang, Vietnam, 12-13 August 2019; pp. $2-4$.

13. Ota, K. The impact of valuation models on value-relevance studies in accounting: A review of theory and evidence. Work. Pap. 2002. [CrossRef]

14. Leuz, C.; Verrecchia, R. The Economic Consequences of Increased Disclosure. J. Account. Res. 2000, 38, 91-124. [CrossRef]

15. Jensen, M.C. Value maximization, stakeholder theory, and the corporate objective function. J. Appl. Corp. Financ. 2001, 14, 8-21. [CrossRef]

16. Gunarathne, N.; Senaratne, S. Country readiness in adopting Integrated Reporting: A Diamond Theory approach from an Asian Pacific economy. In Sustainability Accounting in the Asia Pacific Region; Lee, K., Schaltegger, S., Eds.; Springer: Cham, Switzerland, 2018; pp. 39-66.

17. Stent, W.; Dowler, T. Early assessments of the gap between integrated reporting and current corporate reporting. Meditari Account. Res. 2015, 23, 92-117. [CrossRef]

18. Kılıç, M.; Kuzey, C. Determinants of forward-looking disclosures in integrated reporting. Manag. Audit. J. 2018, 33, 115-144. [CrossRef]

19. Barth, M.E.; Li, K.; McClure, C. Evolution in Value Relevance of Accounting Information. 2018. Available online: https://papers.ssrn.com/sol3/papers.cfm?abstract_id=2933197 (accessed on 15 March 2020).

20. Caglio, A.; Melloni, G.; Perego, P. Informational content and assurance of textual disclosures: Evidence on integrated reporting. Eur. Account. Rev. 2020, 29, 55-83. [CrossRef]

21. Nicolò, G.; Zanellato, G.; Tiron-Tudor, A. Integrated Reporting and European State-Owned Enterprises: A Disclosure Analysis Pre and Post 2014/95/EU. Sustainability 2020, 12, 1908. [CrossRef]

22. IIRC. Towards Integrated Reporting, Communicating Value in the 21st Century 2011. Available online: http://integratedreporting.org/wp-content/uploads/2011/09/IR-Discussion-Paper-2011_spreads.pdf (accessed on 18 June 2019).

23. Tlili, M.; Ben-Othman, H.; Hussainey, K. Does integrated reporting enhance the value relevance of organizational capital? Evidence from the South African context. J. Intellect. Cap. 2019, 20, 642-661. [CrossRef] 
24. IIRC. The International <IR > Framework. 2013. Available online: http://integratedreporting.org/wp-content/ uploads/2013/12/13-12-08-THE-INTERNATIONAL-IR-FRAMEWORK-2-1.pdf (accessed on 18 June 2019).

25. Camodeca, R.; Almici, A.; Sagliaschi, U. Sustainability Disclosure in Integrated Reporting: Does It Matter to Investors? A Cheap Talk Approach. Sustainability 2018, 10, 4393. [CrossRef]

26. Dicorato, S.L.; Di Gerio, C.; Fiorani, G.; Paciullo, G. Integrated Reporting in Municipally Owned Corporations: A Case Study in Italy. In New Trends in Public Sector Reporting; Palgrave Macmillan: Cham, Switzerland, 2020; pp. 175-194.

27. Eccles, R.G.; Saltzman, D. Achieving sustainability through integrated reporting. Stanf. Soc. Innov. Rev. 2011, 9, 56-61.

28. de Villiers, C.; Venter, E.R.; Hsiao, P.C.K. Integrated reporting: Background, measurement issues, approaches and an agenda for future research. Account. Financ. 2017, 57, 937-959. [CrossRef]

29. Dumay, J.; Bernardi, C.; Guthrie, J.; Demartini, P. Integrated reporting: A structured literature review. Account. Forum 2016, 40, 166-185. [CrossRef]

30. Hamad, S.; Draz, M.U.; Lai, F.-W. The Impact of Corporate Governance and Sustainability Reporting on Integrated Reporting: A Conceptual Framework. Sage Open 2020, 10, 1-15. [CrossRef]

31. Karğın, S. The impact of IFRS on the value relevance of accounting information: Evidence from Turkish firms. Int. J. Econ. Financ. 2013, 5, 71-80. [CrossRef]

32. Ohlson, J.A. Earnings, book values, and dividends in equity valuation. Contemp. Account. Res. 1995, 11, 661-687. [CrossRef]

33. Moneva, J.M.; Cuellar, B. The value relevance of financial and non-financial environmental reporting. Environ. Resour. Econ. 2009, 44, 441-456. [CrossRef]

34. de Klerk, M.; de Villiers, C. The value relevance of corporate responsibility reporting: South African evidence. Meditari Account. Res. 2012, 20, 21-38. [CrossRef]

35. Uyar, A.; Kılıç, M. Value relevance of voluntary disclosure: Evidence from Turkish firms. J. Intellect. Cap. 2012, 13, 363-376. [CrossRef]

36. de Villiers, C.; Mia, D.; Marques, A. CSR Disclosure, Dividend Pay-Outs and Firm Value: Relations and Mediating Effects. 2019. Available online: https://cdn.whu.edu/fileadmin/Faculty/Chairs/Chair_of_ Corporate_Finance/CSR_Conference/CSR_dividends_-_AAA_2019_Final_-_Marques.pdf (accessed on 16 March 2020).

37. Healy, P.M.; Palepu, K.G. Information asymmetry, corporate disclosure, and the capital markets: A review of the empirical disclosure literature. J. Account. Econ. 2001, 31, 405-440. [CrossRef]

38. Adhariani, D.; de Villiers, C. Integrated reporting: Perspectives of corporate report preparers and other stakeholders. Sustain. Account. Manag. Policy J. 2019, 10, 126-156. [CrossRef]

39. Verrecchia, R.E. Discretionary disclosure. J. Account. Econ. 1983, 5, 179-194. [CrossRef]

40. Verrecchia, R.E. Information quality and discretionary disclosure. J. Account. Econ. 1990, 12, 365-380. [CrossRef]

41. Cosma, S.; Soana, M.G.; Venturelli, A. Does the market reward integrated report quality? Afr. J. Bus. Manag. 2018, 12, 78-91.

42. Loprevite, S.; Ricca, B.; Rupo, D. Performance sustainability and integrated reporting: Empirical evidence from mandatory and voluntary adoption contexts. Sustainability 2018, 10, 1351. [CrossRef]

43. Vitolla, F.; Raimo, N.; Rubino, M.; Garzoni, A. How pressure from stakeholders affects integrated reporting quality. Corp. Soc. Responsib. Environ. Manag. 2019, 26, 1591-1606. [CrossRef]

44. Flores, E.; Fasan, M.; Mendes-da-Silva, W.; Sampaio, J.O. Integrated reporting and capital markets in an international setting: The role of financial analysts. Bus. Strategy Environ. 2019, 28, 1465-1480. [CrossRef]

45. Landau, A.; Rochell, J.; Klein, C.; Zwergel, B. Integrated reporting of environmental, social, and governance and financial data: Does the market value integrated reports? Bus. Strategy Environ. 2020, 29, 1750-1763. [CrossRef]

46. Donaldson, T.; Preston, L.E. The stakeholder theory of the corporation: Concepts, evidence, and implications. Acad. Manag. Rev. 1995, 20, 65-91. [CrossRef]

47. Benson, B.W.; Davidson, W.N. The relation between stakeholder management, firm value, and CEO compensation: A test of enlightened value maximization. Financ. Manag. 2010, 39, 929-964. [CrossRef]

48. Cook, K.A.; Romi, A.M.; Sánchez, D.; Sánchez, J.M. The influence of corporate social responsibility on investment efficiency and innovation. J. Bus. Financ. Account. 2019, 46, 494-537. [CrossRef] 
49. Margolis, J.D.; Walsh, J.P. Misery loves companies: Rethinking social initiatives by business. Adm. Sci. Q. 2003, 48, 268-305. [CrossRef]

50. Garriga, E.; Melé, D. Corporate social responsibility theories: Mapping the territory. J. Bus. Ethics 2004, 53, 51-71. [CrossRef]

51. Walters, D.; Helman, D. Changing Perspectives of "Value". In Strategic Capability Response Analysis; Springer: Cham, Switzerland, 2020; pp. 7-33.

52. Jones, T.M.; Felps, W.; Bigley, G.A. Ethical theory and stakeholder-related decisions: The role of stakeholder culture. Acad. Manag. Rev. 2007, 32, 137-155. [CrossRef]

53. Asein, A.A.; Adegbie, F.F.; Akintoye, I.R. Effects of the Adoption of Integrated Reporting on the Information Needs of Capital Providers: Evidence from Nigeria. Int. J. Bus. Soc. Sci. 2020, 11, 218-232. [CrossRef]

54. Roman, A.G.; Mocanu, M.; Hoinaru, R. Disclosure style and its determinants in integrated reports. Sustainability 2019, 11, 1960. [CrossRef]

55. Vitolla, F.; Salvi, A.; Raimo, N.; Petruzzella, F.; Rubino, M. The impact on the cost of equity capital in the effects of integrated reporting quality. Bus. Strategy Environ. 2019, 29, 519-529. [CrossRef]

56. Biondi, L.; Dumay, J.; Monciardini, D. Using the International Integrated Reporting Framework to comply with EU Directive 2014/95/EU: Can we afford another reporting façade? Meditari Account. Res. 2020, 28, 889-914. [CrossRef]

57. de Villiers, C.; Sharma, U. A critical reflection on the future of financial, intellectual capital, sustainability and integrated reporting. Crit. Perspect. Account. 2017, 70, 101999. [CrossRef]

58. Badia, F.; Di Cuonzo, G.; Petruzzelli, S.; Dell'Atti, V. The role of stakeholder engagement in the measurement, management and reporting of intellectual capital: A qualitative analysis on IR practices. In Qualitative Research in Intangibles. Intellectual Capital and Integrated Reporting Practices; Roma Tre-Press: Roma, Italy, 2019; pp. 41-63.

59. Farneti, F.; Casonato, F.; Montecalvo, M.; de Villiers, C. The influence of integrated reporting and stakeholder information needs on the disclosure of social information in a state-owned enterprise. Meditari Account. Res. 2019, 27, 556-579. [CrossRef]

60. Queen, P.E. Enlightened shareholder maximization: Is this strategy achievable? J. Bus. Ethics 2015, 127, 683-694. [CrossRef]

61. Lougee, B.; Wallace, J. The corporate social responsibility (CSR) trend. J. Appl. Corp. Financ. 2008, 20, 96-108. [CrossRef]

62. Herath, R.; Gunarathne, A.D.N. Assessing the Gap between Integrated Reporting and Current Integrated Corporate Reporting Practice: A Proposed Checklist. In Proceedings of the 11th Faculty of Management Studies and Commerce (FMSC) Research Symposium, University of Sri Jayewardenepura, Gangodawila, Nugegoda, Sri Lanka, 19 August 2016; pp. 40-52.

63. Stemler, S.E.; Tsai, J. Best practices in interrater reliability: Three common approaches. In Best Practices in Quantitative Methods; Osborne, J.W., Ed.; Sage: Los Angeles, CA, USA, 2008; pp. 29-49.

64. Alfaraih, M.M.; Alanezi, F.S. Does voluntary disclosure level affect the value relevance of accounting information? Account. Tax. 2011, 3, 65-84.

65. Judge, G.; Hill, R.; Griffiths, W.; Lee, T. The Theory and Practice of Econometrics, 2nd ed.; John Wiley and Sons: New York, NY, USA, 1985.

66. Durbin, J.; Watson, G.S. Testing for serial correlation in least-squares regression II. Biometrika 1951, 38, $159-178$. [CrossRef] [PubMed]

67. Islam, M.R.; Khan, T.; Choudhury, T.; Adnan, A. How Earning Per Share (EPS) affects on share price and firm value. Eur. J. Bus. Manag. 2014, 6, 97-108.

68. Central Bank of Sri Lanka. Financial System Stability Review 2019. Available online: https://www.cbsl.gov. lk/sites/default/files/cbslweb_documents/publications/fssr/fssr_2019e.pdf (accessed on 26 July 2020).

69. Sutopo, B.; Kot, S.; Adiati, A.K.; Ardila, L.N. Sustainability Reporting and value relevance of financial statements. Sustainability 2018, 10, 678. [CrossRef]

70. Easton, P.; Shroff, P.; Taylor, G. Permanent and transitory earnings, accounting recording lag, and the earnings coefficient. Rev. Account. Stud. 2000, 5, 281-300. [CrossRef]

71. Kothari, S.; Zimmerman, J. Price and return models. J. Account. Econ. 1995, 20, 155-192. [CrossRef] 
72. ACCA. Meeting Users' Information Needs: The Use and Usefulness of Integrated Reporting 2016. Available online: https://www.accaglobal.com/content/dam/ACCA_Global/Technical/integrate/pi-use-usefulness-ir. pdf (accessed on 18 June 2019).

73. Gunarathne, A.D.N.; Alahakoon, Y. Environmental management accounting practices and their diffusion: The Sri Lankan experience. Nsbm J. Manag. 2016, 2, 1-26. [CrossRef]

74. Senaratne, S.; Gunarathne, A.D.N. Excellence perspective for management education from a global accountants' hub in Asia. In Management Education for Global Leadership; Baporikar, N., Ed.; IGI Global: Hershey, PA, USA, 2017; pp. 158-180.

(C) 2020 by the authors. Licensee MDPI, Basel, Switzerland. This article is an open access article distributed under the terms and conditions of the Creative Commons Attribution (CC BY) license (http://creativecommons.org/licenses/by/4.0/). 